
Journal

$20 \mid 2019$

Sedition, Sexuality, Gender, and Gender Identity in South Asia

\title{
Caste, Queerness, Migration and the Erotics of Activism
}

An Interview with Filmmaker Moses Tulasi

Kareem Khubchandani

\section{OpenEdition \\ Journals}

\section{Electronic version}

URL: http://journals.openedition.org/samaj/7173

DOI: $10.4000 /$ samaj.7173

ISSN: $1960-6060$

Publisher

Association pour la recherche sur l'Asie du Sud (ARAS)

\section{Electronic reference}

Kareem Khubchandani, "Caste, Queerness, Migration and the Erotics of Activism", South Asia

Multidisciplinary Academic Journal [Online], 20 | 2019, Online since 02 May 2019, connection on 11

March 2021. URL: http://journals.openedition.org/samaj/7173 ; DOI: https://doi.org/10.4000/samaj. 7173

This text was automatically generated on 11 March 2021.

\section{cc) (ㅇ) $\ominus$}

This work is licensed under a Creative Commons Attribution-NonCommercial-NoDerivatives 4.0 International License. 


\title{
Caste, Queerness, Migration and the Erotics of Activism
}

\author{
An Interview with Filmmaker Moses Tulasi
}

Kareem Khubchandani

1 Fall 2008. Moses typed "Indian," into the search box of Craigslist-Chicago's Men Seeking Men page. Maybe he would find another Indian man to have sex with. Maybe someone had listed "Indian" as a preferred category for a sexual partner-rare, but not impossible. Since the recent end to his arranged marriage, he had the privacy and mobility to freely engage in casual sex with men. Moses' divorce, and his coming out to his family in Hyderabad, also heralded the end of a nine-year relationship with his college sweetheart Dev. ${ }^{1}$ Dev too had moved from Hyderabad to the Midwest, but preferred that Moses stayed married and closeted, like himself. Moses' Craigslist search yielded an advertisement for an LGBT South Asian potluck, hosted by the very new organization, Trikone-Chicago. The founder of Trikone-Chicago, a young suburban desi, had a stroke of risky brilliance, and posted the potluck details on Craigslist personals. ${ }^{2}$ Moses arrived alone at the potluck in Evanston. After he introduced himself as "an IT guy" and "a project manager," I quickly decided that he was uninteresting. $\mathrm{He}$, on the other hand, had designs on me, and was disappointed that I left early; he had hoped to pick me up that night. He told me this in a research interview several years later. We were best friends by then.

2 Moses arrives at this nascent organization, and discovers a queer South Asian community, through his search for sex. Who could have predicted that this search for sex might set in motion a variety of experiences that culminated with his arrest on the University of Hyderabad campus in March 2016, accused of anti-Indian activity while he filmed activism and protests in the wake of Rohith Vemula's death? This essay, based on early conversations and fieldwork with Moses between 2010 and 2014, as well as a 2017 interview transcript documenting his experiences at the UoH, offers anecdotes and theorizations about how queerness, migration, and caste matter to each other. These "entanglements," material imbrications and discursive confluences, ${ }^{3}$ offer new facets to the study of sedition in India by centering an unlikely and even accidental 
protagonist: a diasporic, queer, Dalit-OBC (other backward caste) filmmaker. ${ }^{4}$ And yet, I contend that it is no accident that he finds himself part of various minoritarian movements, given the imbrication of erotics and activism that creates productive and messy overlaps across sociopolitical positions. This "accidental protagonist," briefly jailed for his trespasses against the nation, helps us see that sedition inhabits the everydayness of being a minoritarian subject, as much as it manifests as explicit forms of political dissent.

3 Activism develops and is sustained by erotics and intimacy. The intensities of being in collective space with others-laughter, flirtations, and silent sadness evidence how politics land on/impact the body, and how bodies shape and make themselves in relation to political structures (Gould 2009; Howe 2013). Queer activism in India is simultaneously "critique, invention, and creative practice": "Acts of same-sex love are not acts of resistance-they are experienced as acts of social and cultural invention." (Dave 2012:14). Moses comes to know himself as an activist and artist through "the erotic," the conjoining of sensuality and activism (Lorde 2007; Gill 2014). His candid approach to sex is a valuable reminder of the erotic possibilities of South Asian LGBTQ community and activist spaces, possibilities that have been effaced in order to present more respectable visions of gayness, driving to the margins casual sex cultures, drag queens and trans people, working class queers, and non-English speaking folks (Gopinath 2005; Rudrappa 2004; Shahani 2008). While I focus on a single person who has emerged as an important queer ally in the anti-caste movement in Hyderabad (Tellis 2016), Moses' narrative helps us think through the productivity of erotics within activism, while also drawing our attention to multiple systems of global and state surveillance he, and those around him, must navigate to find sex and share joy.

Moses and I grew close as we co-organized a queer Bollywood party together, a fundraiser for Trikone. He simultaneously started a business in India, outsourcing some of his US company's labor to his own family and friends there. As he hired his best friend, family members, and eventually his boyfriend, to run this BPO (Business Process Outsourcing company), even his workplace became a site of "intimate" entanglements (Wilson 2004). While setting up this business in India, he entered Hyderabad's gay subcultures: Saturday club nights, house parties filled with mujras [dance performances], public cruising, and casual sex facilitated by online media. In these worlds, he met Jay ${ }^{5}$ who became his boyfriend, manager of the Hyderabad office, and partner for five years. Moses and Jay have hosted parties for Trikone in their Chicago home, and birthday parties in Hyderabad for their queer friends. These spaces erupted in performance: improvised mujras featuring melancholy Aishwariyas, mustached Madhuris, and skinny Salmans. Where middle- and upper-class gay men in India and the USA show a preference for nightlife in commercial venues (Khubchandani 2018), this couple, with their access to private residential space, cultivated the opportunity for intimate performances, amenable to gender transgressions, class-mixing, and sexual liaisons.

5 Moses easily moved back and forth between Hyderabad and Chicago with his creation of a subsidiary company, but he had to be more creative in acquiring work visas for Jay in order to get him to the USA, and eventually secure his Green Card. ${ }^{6}$ While Jay's initial visit was meant to be a short one, it became urgent that he stay longer. Not even a month after he arrived in America, Hyderabad's TV9 aired the notorious exposé that outed men looking for sex with other men online and at clubs, repeatedly broadcasting 
Jay's profile picture, taken from an online social networking website (Singh 2018). ${ }^{7}$ Long before Moses envisioned a film about queer activism in India, he found himself in regular contact with Indian activists because of this scandal.

6 Moses has long had a passion for films and filmmaking, taking classes in camerawork, direction, and editing while in Chicago. Participating in and organizing diasporic LGBTQ events such as parties, film festivals, and parades informed his decision to document pride celebrations in Hyderabad in $2015 .{ }^{8}$ Working alongside the organizers of the Hyderabad event, Moses conducted interviews during and after the Swabhimana Yatra [walk of self-respect], and collected footage and photographs of the walk. This march, it turns out, was the first Pride March in the new state of Telangana, and the film contemplates social and national politics of queer life in India, focusing particularly on regional, caste, transgender, and indigenous investments in staging a queer public. The centralization of Dalit/bahujan identities at this march set in motion "a deluge of assertion of Dalit identities in queer spaces across the country" (Jyoti 2017). As Moses worked on the film, pre-screening various cuts and, in essence, allowing the community to edit this documentary with him, he acquired a newfound language to talk about privilege and equity. His film also made him accountable to trans, Dalit, and queer activists in Hyderabad. Moses' arrival in spaces of activism does not only begin with sexual desire, but it is moved along and fostered by it.

7 In March 2016, Moses brought his camera to the University of Hyderabad grounds to document protests against the campus administration and politicians who refused to take responsibility for the disenfranchisement of Dalit students and the death of graduate student Rohith Vemula. In January 2016, Vemula took his life after the UoH ended his graduate fellowship because of his agitation-on behalf of the Ambedkar Students Association-against Brahmanical and Islamophobic administrators and student groups. Vemula's death came in the wake of ten other suicides by Dalit and tribal students at the UoH and sparked months of protest by students, activists, and community members (Sukumar 2016). The university and police surveillance of protests on campus was intensified by eruptions on the Jawaharlal Nehru University campus following the arrest of the Students' Union president on charges of sedition in February 2016. Unlike news journalists on the UoH campus who had enough warning to leave the premises or move to the periphery of the arrests, Moses did not. He was arrested along with 24 students, and two faculty members, and incarcerated for a week on charges of vandalism. During his arrest, he was accused of throwing stones at the police and being a "propaganda maker"; implicit here is that this "propaganda" is antigovernment, anti-Indian, and anti-police, all premises under which the charge of sedition has been applied (Narrain 2011).

8 Moses' filming and arrest incorporate him into the recent narrative of "seditious" activism. He arrives here via diasporic visions of sexual liberation, via familial pressures of heteronormativity, via Craigslist, nightclubs, and house parties, mujras and drag shows, marches and films, news stings and hook ups. While Moses rode in a car from the jail to his home just after being released on bail, Jay in Chicago dialed me into a three-way call with Moses. His response to "How are you feeling?" was met with an explanation of how hot and smart the other men arrested with him were, how turned on he was by the intense conversations they had about liberation, and the kind of sex that could have been had if there was access to private space in jail. Far from dismissing the political urgencies and trauma of his arrest, Moses' playful comments draw our 
attention to the creative and bodily labor of surviving incarceration. His comments about the time he spent in jail turn us back to the erotics of sedition, the pleasures we might take in being the bad subject in the face of the state's normativity, and the sensual, embodied, and co-present nature of engaging in the work of social change.

So far, I have looked at the ways in which erotics invite Moses into new realms of sociality that transform him from what he calls a "robo-engineer" into a filmmaker and activist. The multiplicity of erotic encounters in his narratives-nightclubs, jails, and Eid festivals-offer a less polished version of India Shining's transnational IT worker. The interview that follows focuses on relationships between caste and queerness, tracing Moses' growing awareness of caste inequity as he moves across national borders, most recently settling back in Hyderabad to make films and produce a web series created by transgender and hijra activists. He expands on the ways that caste becomes a necessary lens of analysis as he thinks about family, religion, desire, and politics.

10 Conjoining activism, migration, sexuality, and caste, Moses offers us a small contribution to the limited theorizations on relationships between caste and queerness. A small body of scholars, novelists, and public intellectuals discuss caste biases in queer Indian activism (Kang 2017a), the sexual fetishization of subordinate castes (Rao 2003, Kang 2017b), and the co-constitutive nature of caste and queerness in law and culture (Jyoti 2018; Baud 2017; Surya 2016). Moses' anecdotes intertwine queer and caste critique as he describes how migrant heteronormativity reproduces caste, and how queer men perform their caste on social media. He is a charming storyteller, drawing our attention to the eroticism of Eid and incarceration, the trauma of arrest and expulsion, and the heteronormativity of suburban American life and caste eradication. The interview relies on our own intimate relationship, as we lay on the guest bed in my parents' house in Bangalore, drinking whisky and talking, our first meeting since his arrest.

\section{Interview with Moses, August $2017^{9}$}

KK: Growing up in India, what was your exposure to social politics: queer, feminist, and class issues?

MT: My family was a little different from pretty much every other family. What made them different was inter-religious and inter-caste marriage. Also the dynamic where my mom was older to my dad and was more educated, and came from a slightly higher class. However, what I would later realize was that she did come from a lower caste. My grandfather's side used education, especially girls' education, as a weapon to navigate the caste-class ladder. So Mom's from a Dalit background. Mom's dad was Dalit. Mom's mom was OBC. Dad's side is OBC.

\section{$\mathrm{KK}:$ What were their religions?}

MT: My mom's a Christian, my dad was a Hindu. He converted to Christianity before the wedding. My dad was never really a religious person but there is that cultural pull, his mom wanted us, the kids, to be Hindu. Dad's side didn't really approve of the marriage; we ended up spending more time with Mom's side. People convert to Christianity not because Jesus saves, but to get away from the ugly caste system of this country, something I realized later. So growing up with these two religious communities, I learnt how to navigate them, navigating friendships. 
KK: What do you mean by "navigating?"

MT: So my friends would be really anxious to know if we celebrated vinkayaka chathurthi with the same fervor that we celebrated Christmas. "By the book you're supposed to be Hindu." Nobody said this to my face, but being identified as a Christian was sort of rebellious in that way, taking your mom's identity. When I realized I was different, in terms of my sexuality, it didn't seem like a big deal to me because: OK yes, I'm considered wrong in all of these things (laughing) I might as well be different in my sexuality. I might as well go and fuck two more guys. We grew up in a locality that had a fair number of Muslims in the community and there was so much peace and harmony between the Muslims, Hindus and Christians, this was in Warangal. And, you know, my friend Sohail, his mom used to buy salwar kameez for me on Eid. I would spend the whole day of Eid gorging on all that food. For Bakr Eid they would sacrifice a goat. It would be a spectacle for all us kids. I mean it was kind of sad to see the goat slaughtered (laughs) in front of your own eyes. I would always turn away at the exact moment when the butcher used to make the cut (hand motion). While the butchering was happening I would be feeling Sohail [up]. (I make a surprised face). None of these things happened in this vacuum, in this very Englishspeaking Bangalore MG Road type of setting. They all happened when Sohail's mother was cooking biryani in the other room, and we were fucking in secrecy, and we could smell the biryani in the room next door. And you know, my grandmother, when she was visiting us, and me and a boy went into my room and locked the door, she knew exactly what was going on. She would come and knock on the door 100 times, she wanted to interrupt. This is the paternal grandmother who is a feminist but also a casteist. She would like-I would only realize later-she would interview all my friends to know their full names. You know why? To learn their [caste].

KK: When did you come to the USA; what brought you?

MT: Ninety-eight. To be honest, I never aspired to. It was a thing I was doing because we all were. My friend Srinivas, he took it upon himself to figure out the US for all of us. He was like, "You like computer science? I'll apply for that for you!" I still remember he pretty much folded my letter and put it in the envelope. My relationship with Dev continued; I think in our relationship we reached around eight years and then a point came in his life, "Now what? Now we both are settled." He came from a very modest background where the mom was the only working person in the family, his dad was a drunkard. His mom used to work two or three jobs to raise the kids. He wanted to give his mom all the happiness he could, so he couldn't afford coming out, he couldn't afford our relationship any more. I didn't want to stand in the way. That was very heartbreaking. So we broke up. He moved on. He got married.

KK: When you think about this move from India to the U.S., what changed in terms of heteronormativity, class, caste, gender? Did things shift with migration or were you reproducing some of the same, you and your friends?

MT: I was living in the closet at that time [in Detroit and Chicago]. Pretty much all evenings were social evenings. We all lived close to each other. You would have to make excuses if you wanted to go to a bar, or go cruising, or you had a hook up over. And I had to live alone, which made my friends very curious because everybody else had roommates; they were living with each other. "Why are you living on your own?" And then the arranged marriages started to happen, in a very heteronormative way. ${ }^{10}$ 
They would not have any qualms sharing, "Today I got this proposal, and this is the girl," and they're showing her to all of us. It was pretty obvious that all the matches that were coming were from the same caste. I had a music band; I used to sing at marriages in Michigan, for a Reddy from some organization, TANA: Telangana Association of North America. And all the leadership was Reddy and Chaudhry, entirely Brahmin and dominant castes. They were the representatives of our culture, they would tell us what to do. [And with these marriages] the competition is: "Which would be the most sanskari bahu for our family?" So then they started marrying and bringing their wives to the US. I started noticing [that] all my friends were kind of reproducing the same model as their parents, right? Here you are in the US, which is supposed to be a land of opportunities, supposed to be an egalitarian [society], this is the notion that we had when [we arrived]. But then we looked at all these educated women who are engineers, who are degree holders, who are accountants, across the spectrum, who all come on a dependent visa, so the dependent visa doesn't allow them to work. ${ }^{11}$ Look at the connection between immigration and patriarchy here: they're supposed to stay at home and cook and clean, it was perfect model for all of these men, and for the in-laws. And then, by the time these people would get green cards, guess what? They would have kids! By the times the first kid is three years old, there goes a decade of your life..$^{12}$ Talking about gender and the Indian context, and propagated patriarchy, I think immigrating to the US for these men is perfect. It's a perfect patriarchy... they don't lose anything at all. Even after I came out to them, one of them called me and he put it point blank, "You would lose out on all your patriarchal benefits if you do this."

KK: When you started coming to Trikone, meeting other queer desis, how did you measure them against what you'd already known?

MT: More than anything else it was liberating to meet other desi queer people. By that time I had experienced racism at the hands of White people in Detroit. Being in the closet you make this grand plan of going to a bar, hours and hours of planning. And you get yourself there and all you have is disappointment. All these fancy stories you see in your mind, you're pre-imagining you'll pick up a hot guy. But none of that happened. ${ }^{13}$ I met a couple of friends. Sure, I had a couple of hook-ups. But when it came to taking it beyond a hook-up, the racism became pretty blatant. This whole dream was not working out. That was the point where I met other queer brown people. And then, when I met you, that was my introduction to the arts in my life. I come from a science background. I'm an engineer right? Although I have a very keen ear for music, an eye for film, but still I was a robo-engineer, and you know, built by those bricks. So it took me a while to sort of shake myself up, and bring out the artistic leanings inside me. That's when I decided I'm going to do something about it, took creative writing, took filmmaking in Chicago.

KK: And after such a rich life in Chicago, what made you think about settling down back in Hyderabad?

MT: The continued, the uh, the continued failures in terms of trying to date somebody local in the US. I mean maybe [no devastating failures], but let's say five failed flings put together they have some effect on you. You like Jack in this bar, you invested some time, you exchanged numbers, you were expecting a second date; that never happened. I [also] really missed the way I was able to get into a relationship in India with the comfort I had with Indian men. It's very difficult for me to be with this 
typical American man's "personal space." The only art that I have is to invade personal space. So I was a no-go when it came to the standard American dating template. I needed a change of scene. I was missing Mom a lot. And I'd finished my filmmaking course so I wanted to make films. I very quickly realized that independent cinema in the US was also completely dominated by White men. And at the same time, Telangana happened. The state of Telangana happened. So [first] the political revolution happened. The arts and culture revolution is happening now.

KK: When we met, I don't remember you really having an investment in the state of Telangana..

MT: I didn't have any opinion at that time. I used to talk to my dad. He and his brother, they went to jail back in the days. They lost one academic year fighting for Telangana. When Telangana happened, it was like, "This actually happened! I need to know more about this. States don't just form." So this Swabhimana Yatra group [documented in Walking the Walk] helped me get a perspective on activism. From there, it was a journey to learn about the Indian Left, Ambedkarites versus the Indian left, versus the right. It was very organic from there. The friendships I made, the travels. I travelled all over India. That film really helped me gain a perspective on the sociocultural scene and how queerness fits into that. And that's when the Rohith Vemula movement started. Rohith had died in January of 2016. The anti-caste movement, there was a sudden uprising across universities: JNU, HCU, NIFT, IITMadras, the Film Institute in Pune. I was really intrigued. What drew me was the brilliantly crafted sloganizing. Slogans like: "Tum kitne Rohith maro gay? Har ghar se Rohith niklega." Look at the rhythm, the recitation of it, the lyrics. Whoever wrote it was brilliant. I want to make a movie on just the slogans. I was drawn through the slogans. It was this force that pulled me in. I went and introduced myself. And of course $\mathrm{B}^{14}$ was at the university. So seeing queer activists actually stand up for an injustice that happened in a non-queer [cause], it was a first for me. B, and a professor, and all these women! "I think I'm in the right place. This feels so liberating. Just the atmosphere. $\mathrm{OK}$, I'm going to roll my camera." I started filming. Every day there would be a protest: Kashmiri movement rights, missing people at the campus. And the campus was beautiful, a free space. One would walk in, there's reporters, intellectuals, writers, all having chai. And I find myself amidst them, talking to people, and rolling my camera, and talking to whoever is comfortable. You go to the canteen area, "shop-com," short for shopping complex, which became the velivada- Dalit ghetto outside of every village. When Rohith and his four colleagues [were refused housing], they set up a tent, a makeshift tent, and they called it velivada, in the shop- com. It's like a courtyard, so all these canteen shops are in a semicircle and there are places to sit. Then I started reading Ambedkar, "I can't do justice to this project if I don't read Ambedkar." The first thing in Ambedkar that caught my attention was: "I was born a Hindu, but I will not die a Hindu." It made me take notice. Things started making sense. I knew that most Christians in India are Dalits. I'm going to jump the timeline: in the jail, there were seven Muslim guys, and once a day [they did] namaz. The entire cell, we would go quiet for their namaz time. There were eight Christians, eight. With the Christians, all of us, we had to secretly pray on Good Friday. There was this mass conversion to Christianity in the fifties and sixties when there was an [upsurge] in anti-caste [activism]. ${ }^{15}$ The government intervened and said, "OK Dalits who are converting to Christianity, you will not get SC reservation, you will get $1 \%$ percent reservation as BC-C category." Many Dalits 
now who profess the Christian faith, they cannot come out as Christian, otherwise they lose their caste reservations. ${ }^{16}$ So even in the jail, these students were afraid, if they actually prayed, if they actually communed as these eight Muslim boys were doing, they would be outed. Fuck! When I was being transferred to the jail, in the van I was so nervous my sexuality would be [outed]. Guess what? People subscribing to the Christian faith was a bigger issue there. People would come out to me in secrecy (laughing). And I'm a Christian and gay (laughing).

KK: Were you out?

MT: So the newspapers outed me. There was an article [that mentioned] "queer filmmaker." One of them, an associate professor of mathematics, also arrested, after five days he said, "Moses, I need to ask, are you gay? I had to know. OK, now let's continue playing carom." These fuckers, these amazing activists, I round them all up and I say, "OK, I'm going to give you LGBT 101 gyan (knowledge)." Five or six of them. Two and a half hours. Questions and questions and questions. It was amazing. There was this cutie, this guard. I mean he was a prisoner but he was given a job of... so the cute boys get good jobs, they have capital, they get biscuits, sweets, attention from men. So cute, Deepak. He was arrested for selling illegal weapons. He had this habit of, he would do this (scratches his crotch gently) and I think he knew; I was like, "Fuck!" I would check him out top to bottom. Every opportunity I got. I was talking to him, having chai, we go in the bathroom and I sort of called him into the bathroom, and he was like, 'There's no door anna, there's no door, so..." So even in the jail, I mean, I didn't have to shut out my sexuality. OK I didn't have sex with him; [but] that [flirtation] was enough. He's beautiful. Deepak was beautiful. That whole thing was beautiful.

KK: You make your time in jail sound romantic and optimistic. Were you worried? Was there trauma?

MT: Ya ya. So uh, I know I make it sound very cool. I was afraid for the longest time. I was afraid of getting beaten. All the horrible things you see on TV and in the movies. I was like, "Fuck. I know I'm in deep shit. And then this policeman, beating the shit out of students. I'm next. OK, we're going to get beaten. Prepare for it. Deep breath. They can beat your body but not your soul. Let them beat you." They slapped me twice, we (Moses and the professor) were slapped twice. But the kids were brutally [beaten], with their elbows. These police were called in, they had no nametags. You could see that their nametags, just before they got into the van, their tags were ripped off so that no one could [identify them]. One of the boys, he had very thick glasses, and if you hit him anywhere near [his eyes], it could affect his nerves. And they bent him over and, "We will hit this area!" [the boy's lower back]. They would use their boots and elbows to hit that area. The Muslims-first of all they would ask for your name. Muslims would be called, "Beef eaters! Pakistanis! Go back to Pakistan! ISIS agents." All kinds of shit. It was traumatic. It was traumatic not being able to do anything for these kids; I'm older than them. Just imagine the professor's plight. He was taken in just because he asked: "Why are you beating my students?" and they said, "You come with us," and they slapped him. They said, "You're teaching anti-national ideas to your kids. It's because of professors like you that these kids are becoming anti national." We were eighteen of us in our van. 
KK: Did it matter you were not a student? You were a wild card in some way.

MT: A little bit. I tried to tell him [police officer], "I just want to clarify, I'm not a student guys." I wanted to get out, get back that video that I took, which they seized. The only card that I had was from the Telangana Producers Association; they said, "This is not a media card." I said, "I'm making a documentary." "I know you, you were siding with the students, you didn't interview us, you only interviewed them." The CI (Chief Inspector) of the police station: "It is because of you guys, you propaganda-makers that the students end up like this. I'm going to make sure you have the same fate as the students." I just shut up. They filed cases against us. They wrote we were throwing stones at them that's why they had arrested us. There was a good view on [footage on] the Internet where I was seen with my camera; blatant lies in their report. It was a very traumatic time. These emotions, the family also is shattered, running around police stations, lawyers, the jail to visit, and there's only two hours to visit. I got out on the morning of the seventh day, the students got out in the evening. Everybody had written eighteen pages of complaints and the news comes that when we are being released maybe the CI will check all our bags. So we had to dispose of everything - the shit hole- we crammed all the papers [into it] and it got blocked and the entire (he gestures to the overflow and I make a face).

KK: So how has this led to where you are now?

MT: I was on the journey of finding the meaning of intersectionality from the Swabhimana Yatra. I was on a slow path. Then I read up on Ambedkar: "We need to represent ourselves in a dignified manner. Gone are the days where I need to follow Gandhi's charade of poverty." My family was a working model of what Ambedkar taught, they followed the path of education, they embraced Christianity, got rid of the day-to-day caste system, and it gave them access to health care and education.

KK: If one strategy is respectability politics-let's dress well, educate ourselves, that uplifts us - and the other is inter-caste marriage that is heteronormative, what is a queer project in the anti-caste movement? What are the queer ways of practicing a different kind of caste politics?

MT: You can go up and down your class, you can change your religion, you can become an atheist, but you can never eradicate caste [yourself]. There's no process of up- casteing yourself or washing away caste [through choice or work]. Although inter-caste marriage is a heteronormative practice, that's how kids are born. I still think inter- caste marriage is a great step. It's a great step. Caste is something very much tied to procreation. I don't see any other way in the near future.

KK: So then, what do inter-caste interactions look like in LGBT organizing?

MT: I'm not going to talk about this LGBT movement as being one big happy family. Gay men, there's blatant casteism on display. There are Grindr profiles with "Reddy" as the name. ${ }^{17}$ "Chaudhry" as the name. Reddy! I sort of lead him on. And then on my twentieth comment, "Hey what do you actually intend by saying you're a Reddy?" "I'm a Reddy, I'm an upper caste, I'm more desirable than anybody else." Or, "I am a Chaudhry," meaning "I'm a great fucker, because we are all great fuckers." Same thing as Jatt. "I'm a Jatt top," rather than... anything else top. Right. Then what I do? of course if he's cute I invite him over and I say, "Is this how much you can fuck? I thought you were a real man? It was only 15 minutes." "No no no, second time." "You need ten minutes [rest]? OK let's get fucking. This time you need to fuck for thirty minutes. I'm going to time you." I humiliate the fuckers, leaving them ashamed of 
their impotence, not being able to satisfy a woman or a bottom. This has become my Grindr game. Any time I see a Reddy or a Chaudhry or a Jatt top on Grindr I do this to them.

KK: It sounds like many of these men are not necessarily part of the queer community and are only looking for sex online. What about casteism in the queer community, amongst activists etc.

MT: Look at Hyderabad. All the leadership is upper caste. More than half of the queer leaders in Hyderabad are upper caste. So anywhere I go, I cannot escape caste. Whether it's my queer politics, whether it's my social standing, whether it's my feminist politics. Most feminist activists in Hyderabad are upper caste.

\section{Conclusion}

11 Through his interview, Moses tracks how caste hierarchy and heteronormativity are complicit projects that render marginal and suspicious those who pursue their pleasures, joy, and dignity. Sedition then is not only located in the realm of rhetorical dissent, but that of the cultures, desires, and the everydays of minoritarian subjects, always bound to politics. The many confluences in Moses's life, set in motion and sustained by erotics, allow us to see how caste, religion, queerness, and migration manifest a dissenting and vulnerable subject.

\section{BIBLIOGRAPHY}

Ameeriar, Lalaie. 2017. Downwardly Global: Women, Work, and Citizenship in the Pakistani Diaspora. Durham: Duke University Press.

Baud, Sumit. 2017. “Invisibility of 'Other' Dalits and Silence in the Law." Biography 40(1):222-94.

Cantú, Lionel, Nancy A. Naples, and Salvador Vidal-Ortiz. 2009. The Sexuality of Migration: Border Crossings and Mexican Immigrant Men. New York: New York University Press.

Chambers-Letson, Joshua. 2018. After the Party: A Manifesto for Queer of Color Life. New York: New York University Press.

Dave, Naisargi. 2012. Queer Activism in India: A Story in the Anthropology of Ethics. Durham: Duke University Press.

Das Gupta, Monisha. 2006. Unruly Immigrants: Rights, Activism, and Transnational South Asian Politics in the United States. Durham: Duke University Press.

Equality Labs. 2018. “Caste in the United States.” Retrieved February 10, 2019 (https://

www.equalitylabs.org/caste-survey-2018/).

Gill, Lyndon. 2014. "In the Realm of Our Lorde: Eros and the Poet Philosopher." Feminist Studies 40 (1):169-98. 
Gopinath, Gayatri. 2005. Impossible Desires: Queer Diasporas and South Asian Public Cultures. Durham: Duke University Press.

Gould, Deborah B. 2009. Moving Politics: Emotion and Act Up's Fight against Aids. Chicago: The University of Chicago Press.

Howe, Cymene. 2013. Intimate Activism: The Struggle for Sexual Rights in Postrevolutionary Nicaragua. Durham North Carolina: Duke University Press.

Jyoti, Dhrubo. 2017. "Being a Queer Dalit, and the Assertion of Dalit Identities in Pride Marches." Feminism in India. Retrieved July 11, 2017 (https://feminisminindia.com/2017/06/22/queer-dalitassertion-pride-marches/)

Jyoti, Dhrubo. 2018. "Caste Broke our Hearts and Love Cannot Put Them Back Together.” BuzzFeed . Retrieved March 2, 2018 (https://www.buzzfeed.com/dhrubojyoti/will-you-buy-me-a-pair-ofshorts).

Kang, Akhil. 2017a. “F*** Me, I Am Dalit.” In Plainspeak. Retrieved October 10, 2017 (http:// www.tarshi.net/inplainspeak/f-me-i-am-dalit/).

Kang, Akhil. 2017b. “Queering Dalit.” Tanqeed. Retrieved September 6, 2017 (http:// www.tanqeed.org/2016/10/queering-dalit-tq-salon/).

Khubchandani, Kareem. 2018. "Cruising the Ephemeral Archives of Bangalore's Gay Nightlife." Pp. 72-96 in Queering Digital India: Activisms, Identities, Subjectivities, edited by R. K. Dasgupta and D. Dasgupta. Edinburgh: Edinburgh University Press.

Lorde, Audrey. 2007. Sister Outsider: Essays and Speeches. Berkeley: Crossing Press.

Majumder, Payel. 2016. "Pride and Prejudice in a Small Town." The Hindu Business Line. Retrieved May 9, 2018 (https://www.thehindubusinessline.com/blink/cover/pride-and-prejudice-in-asmall-town/article21987731.ece1).

Mallapragada, Madhavi. 2014. Virtual Homelands: Indian Immigrants and Online Cultures in the United States. Chicago: University of Illinois Press.

Narrain, Siddharth. 2011. “'Disaffection' and the Law: The Chilling Effect of Sedition Laws in India." Economic and Political Weekly 46(8):33-37.

PTI. 2016. "Supreme Court to Examine Quota Benefit to Dalit Converts." The Hindu, December 17. Retrieved February 10, 2019 (http://www.thehindu.com/news/national/Supreme-Court-toexamine-quota-benefit-to-Dalit-converts/article15527648.ece).

PUCL-K. 2012. Attacking Pubs and Birthday Parties: Communal Policing by Hindutva Outfits. Mangalore: People's Union for Civil Liberties Karnataka and Forum against Atrocities on Women.

Purkayastha, Bandana and Shweta Majumdar Adur. 2013. "On the Edges of Belonging: Indian American Dalits, Queers, Guest Workers, and Questions of Ethnic Belonging." Journal of Intercultural Studies 34(4):418-30.

Rao, Raj R. 2003. The Boyfriend. New Delhi: Penguin.

Roy, Sandip. 1998. “Curry Queens and Other Spices.” Pp 256-63 in Q \& A: Queer in Asian America, edited by A. Hom and D. Eng. Philadelphia: Temple University Press.

Rudrappa, Sharmila. 2004. Ethnic Routes to Becoming American: Indian Immigrants and the Cultures of Citizenship. New Brunswick, NJ: Rutgers University Press. 
Sabrang Staff. 2017. "Why Should Dalit Christians not get Reservations as Scheduled Castes, Notice to Centre: SC.” Sabrang. Retrieved Feb 10, 2019 (https://sabrangindia.in/article/whyshould-dalit-christians-not-get-reservations-scheduled-castes-notice-centre-sc).

Shahani, Parmesh. 2008. Gay Bombay: Globalization, Love and (Be)Longing in Contemporary India. Thousand Oaks, CA: Sage.

Singh, Pawan. 2018. "The TV9 Sting Operation on PlanetRomeo: Absent Subjects, Digital Privacy, and LGBTQ Activism." Pp. 132-50 in Queering Digital India: Activisms, Identities, Subjectivities, edited by R. K. Dasgupta and D. Dasgupta. Edinburgh: Edinburgh University Press.

Sukumar, N. 2016. “'Red Sun in the Blue Sky': Rohith Vemula's Utopian Republic.” Social Change 46 (3):451-57.

Surya. 2016. "The Failed Radical Possibilities of Queerness in India." Raiot. Retrieved October 10, 2017 (http://raiot.in/the-failed-radical-possibilities-of-queerness-in-india/).

Tellis, Ashley. 2016. "The Deafening Silence of the Queer Community Even When Its Own Members Are Attacked is Shocking." Gaylaxy. Retrieved April 1, 2016 (http:// www.gaylaxymag.com/blogs/the-silence-of-the-queer-community-against-attacks-on-itsmembers-is-shocking/\#gs.2ipg94).

Wilson, Ara. 2004. The Intimate Economies of Bangkok: Tomboys, Tycoons, and Avon Ladies in the Global City. Berkeley: University of California Press.

\section{NOTES}

1. Name changed.

2. It is worth noting that in 2018, Craigslist removed its personals section in compliance with the FOSTA/SESTA anti-trafficking bill. While the personals website was not used only by sex workers, the company could not risk its other services being compromised by the increasing anti-sex work surveillance of the Trump administration. This not only removes sex from the public sphere, but prevents the kinds of serendipitous acts of public intimacy that enabled Moses's entrance into the queer South Asian community.

3. I borrow "entanglements" from Joshua Chambers-Letson (2018) who uses the term to think both about embodied intimacies between minoritarian subjects, as well as historical and discursive overlaps of different socio-cultural constituencies.

4. Bandana Purkayastha (2013) argues that it is necessary to consider how Indian American identity is also constituted by the marginalization of various people within the ethnic category, including Dalits, guest workers, and queer folk. My essay is an opportunity to think further about how the queer, OBC, guest worker's marginality comes to matter both in India and the USA.

5. Name changed.

6. Routes of migration, including labor migration, and the makings of diaspora are engendered by queer intimacy (Cantú 2009).

7. This TV9 scandal was far from exceptional; Indian news media regularly colludes in right wing Hindu, heteronormative, casteist moral-policing (PUCL-K 2012)

8. As Monisha Das Gupta (2006) argues, transnational circuits of displacement and migration have played a central role in formations of queer South Asian activism.

9. This interview has been edited for clarity; footnotes have also been added.

10. In 2018, Equality Labs released a report, Caste in the United States, detailing how the Indian caste system travels and is reproduced in the diaspora, and also describing the extraordinary discrimination and violence that members of subordinate castes experience. 
11. Madhavi Mallapragada's (2014) study of women on spousal visas, many of them wives of engineers and IT professionals, reiterates the ways that gender subordination is made systemic through immigration policy.

12. In a parallel context, Lalaie Ameeriar's (2017) study of Pakistani migrant women in Canada shows how the expectation to have and raise children, alongside acquiring new labor certification and residential paperwork leads to the "deskilling" of labor.

13. Moses' comments here reflect the work of public intellectual Sandip Roy (1998), who similarly contemplates how desire, expressed by White men especially, works to affirm one's arrival and welcome as an immigrant.

14. Name changed.

15. In 1956, following Babasaheb Ambedkar's example, there were mass conversions of Dalits to Buddhism. While Christian conversions are not documented at the same magnitude, there are ongoing conversions, though they do not always guarantee freedom from caste prejudice.

16. Dalit Christians and Muslims are denied reservations allotted to scheduled castes. Reservations are meant to secure university admission and aid for historically marginalized groups; however Dalit reservations are available only to Hindu, Sikh, and Buddhist Dalits. Many Dalits converted, and continue to convert, to Christianity in order to escape the trappings of the Vedic-based (and state sanctioned) hierarchy. However, religious conversion does not guarantee social or economic mobility and so Dalits have appealed to the Supreme Court to review the reservation system. See Sabrang Staff (2017), PTI (2016).

17. Geographer Dhiren Borisa articulates similar findings in his research on caste and queerness, further offering "instances of people who were denied admission to gay social networking sites such as Grindr and Planet Romeo, for declaring that they belonged to a lower caste," (Majumder 2016).

\section{ABSTRACTS}

This hybrid essay-interview draws on the experiences of diasporic, queer, Dalit-OBC filmmaker Moses Tulasi to explore the mutually constitutive roles of sexuality, caste, migration, art, and activism. In March 2016, Tulasi was arrested on the University of Hyderabad grounds, amidst protests elicited by the death of Dalit graduate student Rohith Vemula; only eight years prior Tulasi was a married, closeted, apolitical "IT guy" living in Chicago's suburbs. The essay traces key moments in Tulasi's life to demonstrate how queer desires and pleasures lead him into radical community, activism, and dissent. These moments include an online search for partners on Craigslist, queer nightlife in Chicago and Hyderabad, and the outing of his partner on national television. Following Moses from his entrance into queer community through to his release from jail, the essay develops erotics as a useful analytic in the study of activism. The accompanying interview with Tulasi centers his own theorizations on these questions. He builds on the above themes, detailing how caste is imbricated in family structures, migration patterns, queer activism, sexual desire, and everyday life. Throughout, Tulasi draws attention to the sensual and erotic textures of living within caste hierarchy, engaging in protest, and espousing dissent. Together, the essay and interview demonstrate that sedition is not only rhetorical dissent, but the everyday condition of being a minoritarian subject in a Brahminical and heteronormative state. 
INDEX

Keywords: caste, creativity, migration, diaspora, erotics, desire, pleasure, queer

\section{AUTHOR}

\section{KAREEM KHUBCHANDANI}

Theater, Dance and Performance Studies, Tufts University 